\title{
THE INFLUENCE OF ORGANIZATION COMMITMENT AND COMPENSATION ON EMPLOYEE PERFORMANCE MEDIATED BY ORGANIZATIONAL CITIZENSHIP BEHAVIOR (OCB)
}

\author{
Mercy Melinda Putria \\ Anis Siti Hartati ${ }^{b}$ \\ Agus Haryadi ${ }^{c}$ \\ Program Studi Manajemen Fakultas Ekonomi dan Bisnis UPN “Veteran" Yogyakarta \\ Email: mercymelindaputri@gmail.com ${ }^{\mathrm{a}}$; anissh fe@yahoo.com ${ }^{\mathrm{b}}$; agusharyadi fe@yahoo.com
}

\begin{abstract}
ARTICLE HISTORY
ABSTRACT

Received:

27 November 2020

Revised

24 May 2021

Accepted:

11 June 2021

Online available:

20 November 2021

Keywords:

Commitment,

Compensation,

Employee

Performance,

Organizational

Citizenship Behavior

Introduction: The purpose of this study is to describe and explain the influence between variables of Organizational Commitment, Compensation, Organizational Citizenship Behavior (OCB), and Employee Performance.

Methods: This study includes quantitative and descriptive research. The sample in the study amounted to 50 employees taken using a saturated sampling technique. The data obtained are analyzed using path analysis.

Results: The results of this study prove that there is a direct significant influence of organizational commitment and compensation on employee performance. In addition, the results of this study also prove that there is no indirect influence of organizational commitment on employee performance mediated by $O C B$ and there is an indirect influence of compensation on employee performance mediated by OCB.

Conclusion and suggestion: The company should focus more on increasing the direct influence of organizational commitment on employee performance.
\end{abstract}

\section{INTRODUCTION}

Human Resources (HR) plays a very dominant and important role in the company's activities. HR capabilities greatly affect the success or failure of a company in achieving its goals. So that employees are required to be able to develop themselves proactively in the company. Currently, the Human Resources needed are Human Resources that produce maximum performance.

The performance of human resources owned by a company can be influenced by several variables, one of which is the organizational commitment variable. Good organizational commitment can improve employee performance. Organizational 
commitment is defined as a condition in which an individual sided with the organization and its goals and desires to maintain membership in the organization (Robbins and Judge, 2009).

The next variable that can affect employee performance is compensation. Hasibuan (2007) defines compensation as all income in the form of money, direct goods or indirect goods received by employees in return for services provided to the company. According to Simamora (2004), good compensation is a compensation system that is responsive to the situation and a system that can motivate employees. If the compensation system applied is able to satisfy the needs of employees, behave fairly in terms of giving compensation and rewarding their performance, then employees will automatically work optimally on fulfill requests from management.

The next important variable that can improve employee performance is the Organizational Citizenship Behavior (OCB) variable. OCB is individual behavior voluntarily (without coercion), indirectly (explicitly) and officially recognized in the reward system OCB that can affect organizational performance, behavior improves work groups because it helps people to work together. According to Dyne (in Chien, 2004) Organizational Citizenship Behavior is a behavioral function and additional roles that direct individuals, groups or organizations to perform additional activities.

This study is conducted at PT. Bank Rakyat Indonesia (Persero) Tbk KC Yogyakarta Adisucipto which an Indonesia-based company engaged in services, especially in the banking sector. Services offered by PT. Bank Rakyat Indonesia (Persero) Tbk KC Yogyakarta Adisucipto itself in the form of various loans and deposits, bill payments, money transfers (transfers), and others. Its products include working capital loans, investment loans, savings accounts, current accounts, and time deposits.

Based on the products offered, of course PT. Bank Rakyat Indonesia (Persero) Tbk KC Yogyakarta Adisucipto is in dire need of human resources with maximum performance in achieving the standards and results desired by the company.

\section{LITERATURE REVIEW}

\section{Organizational Commitment}

According to Robbins (2013) organizational commitment is defined as a condition in which an individual sided with the organization and its goals and desires to maintain membership in the organization. Allen and Meyer (1990) divide organizational commitment into three dimensions of assessment, namely:

a. Affective Commitment

b. Continuance Commitment 
c. Normative Commitment

\section{Compensation}

Compensation is all remuneration in the form of money, goods or enjoyment provided by the company to employees for the performance that is donated to the company (Kadarisman, 2012). The indicators that can be used to measure employee compensation according to Simamora (2004) are as follows:
a. Wages and Salaries
b. Incentive
c. Allowance
d. Facilities

\section{Organizational Citizenship Behavior (OCB)}

According to Dyne (in Chien, 2004) organizational citizenship behavior or often called Organizational Citizenship Behavior is a behavioral function and additional roles that direct individuals, groups or organizations to perform additional activities. The following are OCB assessment indicators according to Organ (1988):
a. Altruism
b. Conscientiousness
c. Sportmanships
d. Courtesy
e. Civic Virtue

\section{Employee Performance}

Employee performance can be interpreted as the result of work in quality and quantity achieved by an employee in carrying out his duties according to the responsibilities given to him (Mangkunegara, 2013). The following are employee performance indicators according to Mangkunegara (2013):
a. Working quality
b. Working Quantity
c. Responsibility
d. Cooperation
e. Work Initiative

\section{RESEARCH METHODS}

This study is conducted at PT. Bank Rakyat Indonesia (Persero) Tbk KC Yogyakarta Adisucipto using descriptive and quantitative approaches. The population in 
this study are all employees of PT. Bank Rakyat Indonesia (Persero) Tbk KC Yogyakarta Adisucipto as many as 50 people. According to Arikunto (2013), if the subject is less than 100 people, all of them should be taken, if the subject is large or more than 100 people can be taken $10-15 \%$ or $20-25 \%$ or more, then the sampling technique used is saturated sampling.

\section{RESULT AND ANALYSIS}

In this study, the characteristics of the respondents are categorized according to gender, age and level of education of employees. Based on the results of the study, it is found that the characteristics based on gender are known to be the most female respondents, namely 34 people (68\%), based on age, the most results are in the age group of 28-36 years, amounting to 28 people (56\%), and based on education level, the result is that the majority of respondents have a background with an undergraduate education level with the amount of 41 people (82\%).

In this analysis, the variables tested are organizational commitment (X1) and compensation (X2) to OCB. The following is the result of path analysis for equation 1 :

Table 2

Results of Path Analysis Equation 1

\begin{tabular}{|c|c|c|c|c|c|c|}
\hline & \multirow{2}{*}{ Model } & \multicolumn{2}{|c|}{$\begin{array}{c}\text { Unstandardized } \\
\text { Coefficients }\end{array}$} & \multirow{2}{*}{$\begin{array}{c}\begin{array}{c}\text { Standardized } \\
\text { Coefficients }\end{array} \\
\text { Beta }\end{array}$} & \multirow[b]{2}{*}{$\mathrm{t}$} & \multirow{2}{*}{ Sig. } \\
\hline & & B & Std. Error & & & \\
\hline \multirow{3}{*}{1} & (Constant) & 11,759 & 6,648 & & 1,769 & 0,083 \\
\hline & $\begin{array}{l}\text { Commitment } \\
\text { Organization } \\
\text { (X1) }\end{array}$ & 0,341 & 0,132 & 0,266 & 2,590 & 0,013 \\
\hline & $\begin{array}{l}\text { Compensation } \\
\text { (X2) }\end{array}$ & 1,153 & 0,182 & 0,651 & 6,324 & 0,000 \\
\hline & $\begin{array}{l}0,728 \\
\mathrm{R}^{2}=0,716 \\
\text { endent Variable }\end{array}$ & & & & & \\
\hline
\end{tabular}

In the path analysis of equation 1 , it can be seen that organizational commitment has an effect on OCB of 0.266 and compensation has an effect on OCB of 0.651 . In addition, it can also be seen that the significance value of organizational commitment is 0.013 and compensation is 0.000 . This shows that organizational commitment and compensation have a significant influence on OCB. Because 0.013 and $0.000<0.05$ which is the limit of the significance level. In this analysis, the variables tested are organizational commitment $(X 1)$ and compensation $(X 2)$ to OCB (Z). The following is the result of path analysis for equation 2 : 
Table 3

Results of Path Analysis Equation 2

\begin{tabular}{|c|c|c|c|c|c|c|}
\hline & \multirow[b]{2}{*}{ Model } & \multicolumn{2}{|c|}{$\begin{array}{l}\text { Unstandardized } \\
\text { Coefficients }\end{array}$} & \multirow{2}{*}{$\begin{array}{c}\begin{array}{c}\text { Standardized } \\
\text { Coefficients }\end{array} \\
\text { Beta } \\
\end{array}$} & \multirow[b]{2}{*}{$\mathbf{t}$} & \multirow[b]{2}{*}{ Sig. } \\
\hline & & B & Std. Error & & & \\
\hline \multirow{4}{*}{2} & (Constant) & $-2,799$ & 2,321 & & $-1,206$ & 0,234 \\
\hline & $\begin{array}{l}\text { Commitment } \\
\text { Organization (X1) }\end{array}$ & 0,280 & 0,048 & 0,394 & 5,897 & 0,000 \\
\hline & $\begin{array}{l}\text { Compensation } \\
\text { (X2) }\end{array}$ & 0,458 & 0,084 & 0,464 & 5,463 & 0,000 \\
\hline & OCB (Z) & 0,105 & 0,049 & 0,188 & 2,123 & 0,039 \\
\hline \multicolumn{7}{|c|}{$\begin{array}{l}\mathrm{R}^{2}=0,902 \\
\text { Adj } \mathrm{R}^{2}=0,895 \\
\text { Dependent Variable: Kinerja Kary }\end{array}$} \\
\hline
\end{tabular}

In the results of the path analysis of equation 2, it can be seen that organizational commitment has an effect on employee performance of 0.394, compensation has an effect of 0.464 and OCB has an effect of 0.188 . It can also be seen that the significance value of organizational commitment is 0.000 , compensation is 0.000 and OCB is 0.039 . This shows that organizational commitment, compensation and OCB have a significant influence on employee performance. Because 0.000 , and 0.000 and $0.039<0.05$ which is the limit of the significance level.

Based on the results of the analysis of the equations of path 1 and path 2, the results of the path analysis test can be presented as follows:

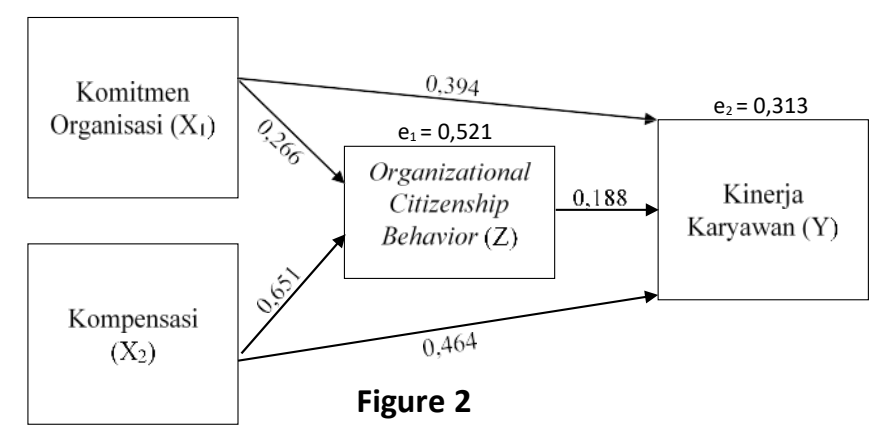

Path Analysis Test Results 


\section{Direct Influence of Organizational Commitment on Employee Performance}

Based on the results of the study indicate that organizational commitment has a direct and significant influence on employee performance. This means that the higher the employee's organizational commitment, the higher the employee's performance will be. Organizational commitment consisting of affective commitment, continuance commitment, and normative commitment, has an influence of 0.394 or $39.4 \%$ on the performance of employees of PT. Bank Rakyat Indonesia (Persero) Tbk KC Yogyakarta Adisucipto. In the table of data tabulation results, the highest average value is 3.84 which represents the affective commitment indicator, while the lowest average value is 3.69 which represents the continuance commitment indicator. PT. Bank Rakyat Indonesia (Persero) Tbk KC Yogyakarta Adisucipto can increase organizational commitment in terms of continuance commitment by providing income and benefits expected by its employees. That way employees will also optimize their performance.

\section{Direct Influence of Compensation on Employee Performance}

Based on the results of the study indicate that compensation has a direct and significant influence on employee performance. This indicates that the higher the compensation received by the employee, the higher the employee's performance. Compensation consisting of salaries, incentives, allowances, and facilities, has an influence of 0.464 or $46.4 \%$ on the performance of employees of PT. Bank Rakyat Indonesia (Persero) Tbk KC Yogyakarta Adisucipto. In the compensation variable assessment table, the highest average value is 4.06 which represents the salary indicator, while the lowest average value is 3.68 which represents the facility indicator. If PT. Bank Rakyat Indonesia (Persero) Tbk KC Yogyakarta Adisucipto can increase the provision of compensation to its employees so that employee performance will also increase.

\section{Indirect Influence of Organizational Commitment on Employee Performance Mediated by OCB}

Based on the results of the Sobel test calculation, it is obtained that t-count is $1.73838<2.01290$, so the influence of organizational commitment on employee performance mediated by OCB at PT. Bank Rakyat Indonesia (Persero) Tbk KC Yogyakarta Adisucipto is not significant, which means that the OCB variable cannot mediate the effect of organizational commitment on employee performance.

This shows that the organizational commitment of employees of PT. Bank Rakyat Indonesia (Persero) Tbk KC Yogyakarta Adisucipto for example in terms of continuance 
commitment which does not consider work as a necessity and does not feel a loss if leaving the current organization can make OCB behavior decreasing and the influence on employee performance will also decrease.

\section{Indirect Influence of Compensation on Employee Performance Mediated by OCB}

Based on the results of the study indicate that compensation has an indirect influence on employee performance mediated by OCB of 0.1223 . Where the direct influence obtained is 0.464 so that the total effect is $0.464+0.1223=0.5863$. Because the indirect influence obtained is smaller than the direct one, the OCB is less able to mediate the effect of compensation on employee performance.

From the results of the Sobel test calculation, it is obtained t-count of 2.57004> 2.01290 meaning the influence of compensation on employee performance mediated by OCB at PT. Bank Rakyat Indonesia (Persero) Tbk KC Yogyakarta Adisucipto is significant. This shows that if the compensation received by the employees of PT. Bank Rakyat Indonesia (Persero) Tbk KC Yogyakarta Adisucipto increases, employee OCB behavior will increase and employee performance will also increase.

\section{CONCLUSION}

There is a direct influence of organizational commitment on employee performance at PT. Bank Rakyat Indonesia (Persero) Tbk KC Yogyakarta Adisucipto. There is a direct influence of compensation on employee performance at PT. Bank Rakyat Indonesia (Persero) Tbk KC Yogyakarta Adisucipto. There is no indirect influence of organizational commitment on employee performance mediated by OCB at PT. Bank Rakyat Indonesia (Persero) Tbk KC Yogyakarta Adisucipto. There is an indirect influence of compensation on employee performance mediated by OCB at PT. Bank Rakyat Indonesia (Persero) Tbk KC Yogyakarta Adisucipto.

\section{SUGGESTION}

Based on the results of the Sobel test calculation, the influence of organizational commitment on employee performance mediated by OCB cannot mediate the effect of organizational commitment on employee performance, so the company should focus more on increasing the direct influence of organizational commitment on employee performance.

The average results per item of the organizational commitment variable on the continuance commitment indicator show the lowest results. Companies can increase 
employee organizational commitment by adding things that can improve the quality of the company such as income and other benefits so that employees will consider if they want to leave the company. These things are like implementing good HR management, for example applying fair and objective assessments. So that employees will feel fair and valued. In addition, the company can also provide a clear career path. One of the considerations for employees to choose a company is their career prospects. The clearer the prospects, the more employees' organizational commitment to the company will increase. If there is an increase in organizational commitment, employee performance will also increase.

In terms of organizational citizenship behavior (OCB), which is a mediating variable, the influence of compensation on employee performance has an indirect influence that is smaller than the direct influence, so the company should improve employee performance by focusing on increasing the direct effect of compensation on employee performance. The compensation variable on the salary indicator represents the facility indicator. The company should increase the compensation, especially in terms of facilities for its employees. At least it can provide psychological consultation for employees who need or canteen facilities in order to save employees time during breaks. Because with this increase in compensation, employees can work more comfortably so that it will improve employee performance in terms of quality, quantity, responsibility, cooperation, and initiative in work.

\section{REFERENCES}

Allen, N.J \& Meyer, J.P. 1990. The Measurement and Antecedents of Affective, Continuance and Normative Commitment to the Organization. Journal ofOccupational Psychology. 63, 1-18

Chien, Huei-min. 2004. An Investigation of The Relationship of Organizational Sturcture, Employee's Personality and OCBs. Journal of American Academy of Business, Cambridge, Vol. 5, pg. 428.

Hasibuan, Malayu S. P. 2001. Manajemen Sumber Daya Manusia. Jakarta: Bumi Aksara.

. 2007. Manajemen Sumber Daya Manusia Perusahaan. Jakarta: Bumi Aksara.

. 2013. Manajemen Sumber Daya Manusia. Cetakan kesembilan. Jakarta: Bumi Aksara.

Kadarisman. (2012). ManajemenKompensasi. Jakarta: Raja GafindoPersada. 
Mangkunegara, Anwar Prabu. 2012. Evaluasi Kinerja Sumber Daya Manusia, Cetakan Keenam. Bandung: Refika Aditama.

. 2013. Manajemen Sumber Daya Manusia, Bandung: PT Remaja Rosdakarya.

2017. Manajemen Sumber Daya Manusia Perusahaan, Bandung: RemajaRosdakarya.

Organ, D.W. (1988). Organizational Citizenship Behavior: The Good Soldier Syndrome. Lexington, MA: Lexington Books.

Robbins, Stephen P. \& Timothy, A. Judge. 2009. Organizational Behavior. 13 th Edition, USA: Pearson International Edition, Prentience-Hall - 2013. Organizational Behavior. Edition 15. New Jersey: Pearson Education.

Simamora, Henry. 1997. Manajemen Sumber Daya Manusia. Yogyakarta: STIE YKPN. . 2004. Manajemen Sumber Daya Manusia, Edisi Ketiga, Cetakan Pertama. Yogyakarta: STIE YKPN . 2006. ManajemenSumber Daya Manusia, Edisi 3.Yogyakarta: STIE YKPN. 